\title{
THEOLOGICKÝ OBRAT JAKO VÝZVA
}

Slova o theologickém obratu ve fenomenologii budí vášně. Když jsem na půdu Filozofické fakulty Univerzity Karlovy pozval Emmanuela Falquea (fenomenologa a theologa $\mathrm{v}$ jedné osobě), abychom debatovali o jeho knize Passer le Rubicon, ${ }^{1}$ namísto dialogu jsme odhalili hluboký př́kop mezi zmíněnými disciplínami. A jelikož Rubikon jako metafora pochází z vojenského, ba válečného prostředí, bylo by možná lépe hovořit o zákopech, z nichž př́islušníci obou táborů jenom nesměle vykukují přes frontovou linii.

Shodnou-li se čeští filosofové a theologové na něčem konkrétním, pak je to právě přesvědčení, že sdílet jeden diskurs a jednu místnost je nepř́ípustné. Nedej bože, abychom se mezi disciplínami svobodně pohybovali a vědomě s tímto pohybem pracovali. Při zmíněném kolokviu hájil tezi o rozdělení a radikální distinkci proti Falqueovi Jakub Čapek. ${ }^{2}$ Theologové se pro jistotu nezúčastnili vůbec.

O vztahu mezi theologií a fenomenologií v české odborné debatě by se dalo říct následující: fenomenologie se štítí theologie jako čert kříže a domácí theologie je od recepce fenomenologie a obecně soudobé kontinentální filosofie ještě několik století vzdálená. A právě proto je nesmírně důležité, že máme v českém překladu k dispozici Janicaudovy kritické spisy. Ještě důležitější se pak zdá, že Petr Prášek začal s těmito texty polemizovat, a otevřel tím debatu, ve které se nejen mnohé o vztahu fenomenologie a theologie může vyjasnit, nýbrž rovněž tím mohou být obě disciplíny podníceny a mohou díky tomu vstoupit do interakce.

1 E. Falque, Passer le Rubicon. Philosophie et théologie. Essai sur les frontières, Paris 2013.

2 J.Čapek, Philosophy and Theology. What Happens When We Cross the Boundary?, in M. Koci - J. Alvis (vyd.), Transforming the Theological Turn. Phenomenology with Emmanuel Falque, London 2020. 


\section{Theologický obrat? Proměna perspektivy}

„Ve francouzské fenomenologii k žádnému theologickému obratu - ve smyslu, jejž tomuto termínu dává Janicaud - nedošlo." 3 S touto tezí nelze než souhlasit. Žádné smíšení disciplín, žádná theologizace fenomenologie. Janicaudův požadavek, aby theologie a fenomenologie font deux, zůstává v platnosti. Práškův text přehledně a úspěšně argumentuje tímto směrem a v tomto ohledu není zapotřebí nikterak polemizovat. Pokusím se ukázat, že na problematiku theologického obratu se ale lze podívat skrze jinou perspektivu.

Prášek upozorňuje, že Janicaud nekritizuje nepopiratelnou inspiraci z theologie a jeho zájem je na prvním místě formální, metodologický. Janicaud opírá svou kritiku o klíčový § 58 prvního svazku Husserlových Idejí k čisté fenomenologii a fenomenologické filosofii, ${ }^{4} \mathrm{v}$ němž je Boží transcendence uzávorkována a vyloučena z fenomenologického zkoumání. A Janicaud připomíná, že nejen poukaz na Boha, ale rovněž jakýkoli poukaz k náboženskému vědomí, které by působilo jako ,šifra transcendence“, je třeba důsledně vyřadit. Separace fenomenologie a theologie, podpořena samotným zakladatelem fenomenologie, je imperativ. Fenomenologie musí zůstat deskriptivní disciplínou se zájmem o korelaci mezi světem a transcendentálním vědomím. Orthodoxní fenomenologie nemá jinou možnost než být minimalistická, atheistická a neutrální.

Ponechme stranou, zda atheistický světonázor je ve srovnání s náboženskou konfesí neutrální. Zajímavější je otázka, zda legitimní požadavek fenomenologa neopustit pole imanence je totéž jako vyloučit vše theologické ze zkoumání zkušenosti. Pozoruhodnou odpověd’ zformuloval dávno před vypuknutím debaty o theologickém obratu Erazim Kohák..$^{5}$ Ten čte Husserlův imperativ ve světle $\$ 24$ Idejí, tedy ve smyslu vyloučení pozitivního Boha jako nahrazení principu všech principů. Slo-

3 P. Prášek, Fenomenologie bez theologie. Nad knihou Dominiqua Janicauda Theologický obrat ve francouzské fenomenologii, viz str. $191 \mathrm{v}$ tomto čísle časopisu.

4 D. Janicaud, Na rozhraních fenomenologie. Transcendence, jevení a zkušenost, přel. M. Pokorný, Praha 2019, str. 59-60.

5 Kredit za objevení Kohákovy relevance pro naši debatu, zejména v případě jeho knihy Idea and Experience. Edmund Husserl's Project of Phenomenology in Ideas I (Chicago 1978), je třeba připsat Ch. Yates, Checking Janicaud's Arithmetic. How Phenomenology and Theology „Make Two“, in: Analecta Hermeneutica, 1, 2009, str. 73-92. 
vy Jana Patočky, Bůh a Boží transcendence pojatá jako noetický princip musí z fenomenologie nutně vypadnout. ${ }^{6}$ A Janicaud má pravdu, že fenomenologické dání smyslu nesmí podlehnout mimosvětskému (theistickému) vysvětlení, což by nebylo ničím jiným než ,projevem naivní metafyziky“? 7

Husserlovu pozici vzhledem k ,absolutnu“ a „transcendenci“ je třeba číst jako obranu proti určitým motivacím náboženského vědomí (posvátné intencionalitě), avšak nikoli jako striktní vyloučení veškerých možností náboženské a theologické manifestace z fenomenologické reflexe. ${ }^{8} \mathrm{~K}$ podobnému závěru dochází více čtenářu Husserla. Například Jana Tratejlová v ojedinělém textu, který se explicitně věnuje tématu theologického obratu v našem jazykovém kontextu, vyjadřuje na základě analýz Husserla přesvědčení, že zahrnout náboženskou zkušenost, a dokonce theologicky relevantní fenomény, je zcela legitimní. ${ }^{9}$ Nabízí se tak otázka, zda Janicaudův atak není motivován poněkud prozaicky, tj. jako vymezení se vůči konkurenčnímu projektu jeho vlastní „minimalistické fenomenologie“.

Inspirace a fenomény z oblasti theologie, zdá se, nezavdávají dostatečně nutnou podmínku pro nezrrízený vpád absolutna do fenomenologie a nepřípustné „stržení kormidla“. Přesto se debata o theologickém obratu točí právě okolo formální otázky legitimity této inspirace. A tak má Jean-Luc Marion ve svém vrcholném fenomenologickém díle Étant donné potřebu obhájit tvrzení, že argument fenomenologie daru/danosti a pojem saturovaného fenoménu nevyrostl na základě theologie..$^{10}$ V nedávném tematickém čísle časopisu Philosophy Today věnovaném „budoucnosti theologického obratu“ se Joseph O’Leary vyslovuje zcela v janicaudovském smyslu, když požaduje vzájemně se vylučující mi-

6 J. Patočka, Theologie a filosofie, in: týž, Sebrané spisy Jana Patočky, I, Péče o duši, I, vyd. I. Chvatík - P. Kouba, Praha 1996, str. 18.

7 D. Janicaud, Na rozhraních fenomenologie, str. 123.

8 Ch. Yates, Checking Janicaud's Arithmetic, str. 89.

9 J. Tratejlová, Vpád Boha do fenomenológie? O možnostiach a hraniciach fenomenológie v rámci diskusie tzv. „teologického obratu“, in: M. Muránsky (vyd.), Náboženstvo a nihilizmus z pohl'adu filozofie existencie a fenomenológie, Bratislava 2010, str. 93-108 (př́íloha č. 1 časopisu Filozofia).

10 Tento pohyb následně kritizuje Marionův žák E. Falque - považuje ho za maskování theologické inspirace, která tvořivě transformuje fenomenologickou praxi, aniž by ji přeznačovala v theologii. Viz E. Falque, Larvatus pro Deo. Phénoménologie et théologie chez J.-L. Marion, in: Gregorianum, 1, 2005, str. 45-62. 
nimalismus jak ve filosofii, tak theologii. ${ }^{11}$ Nakonec i sám Dominique Janicaud, přes veškeré deklarace, že označení „noví theologové“12 je míněno metaforicky, není tak úplně věrný svému výroku a do theologie, respektive do theologických inspirací jemu znelíbených fenomenologů, se vehementně naváží. ${ }^{13} \mathrm{~V}$ pojetí minimalistické fenomenologie není legitimní žádný kontakt s theologií a náboženstvím. Pro jistotu je vyřazen i „,nepublikovaný Husserl“, ve kterém by snad jisté otevření fenomenologie theologickým tématům (avšak nikoli theologizaci fenomenologie jako takové) mohlo vysvitnout. ${ }^{14}$

Je nepopiratelné, že v určitých fenomenologických kruzích hraje theologická inspirace podstatnou roli. Je evidentní, že jistý směr kontinentální filosofie náboženství (která bují především v anglo-americkém akademickém diskursu jako protipól analytické filosofické theologii) z francouzské fenomenologie nejen vehementně čerpá inspiraci pro analýzu náboženských fenoménů, ale také ji chápe jako otevření pole pro zkoumání prostoru mezi filosofií a theologií. ${ }^{15}$ A je nezpochybnitelné, že autoři jako Levinas, Marion, Henry, Chrétien a v následující generaci Lacoste a Falque mají tu více tu méně explicitně vyjádřené theologické zájmy. At' se rozhodneme hájit fenomenologii minimalistickou a prihlásíme se k Janicaudem vyznávané husserlovské orthodoxii, nebo dáme přednost maximalistickému pojetí generace nových francouzských fenomenologů, nebo potvrdíme rozlišení disciplín theologie a filosofie a budeme hájit jejich autonomii, v každém ohledu se vtírá otázka po relevanci theologického obratu, resp. nové francouzské fenomenologie.

11 J. O'Leary, Phenomenology and Theology. Respecting the Boundaries, in: Philosophy Today, 1, 2018, str. 99-118.

12 D. Janicaud, Na rozhraních fenomenologie, str. 88.

13 Tamt., str. $57 \mathrm{n}$.

14 Tamt., str. 125. Jean Greisch ovšem nabízí zcela jiný pohled na napětí mezi publikovaným, př́isně atheistickým Husserlem a Husserlem nevydaných rukopisů. Greisch uznává, že v principu jde Janicaudova diagnóza stavu fenomenologie správným směrem. Nicméně dodává, že postavit proti sobě Husserla a „nové fenomenology“ není ospravedlnitelné. J. Greisch, The Same and the Other. Philosophy and Theology in the Twentieth Century, in: N. Gronkjaer (vyd.), The Return of God. Theological Perspectives in Contemporary Philosophy, Odense 1998, str. 49-73.

15 S tímto úmyslem založili v roce 2015 Emmanuel Falque a Richard Kearney profesní sít' International Network in Philosophy of Religion. Jde o sdružení filosofů a theologů v jedné organizaci, která vyrostla na pozadí zájmu o mnohočetné dílo autorů tzv. theologického obratu, viz www.network-inpr.org. 
Zajímavé na celé debatě však není to, zda někteří fenomenologové jsou krypto-theologové. Nejsou! Petr Prášek podal přesvědčivou obhajobu a postačí odkázat k jeho textu. Skutečně zajímavou otázkou, která však byla ve formální diskusi o (ne)legitimitě odložena stranou, je: Kam theologický obrat, resp. fenomenologie otevřená theologické inspiraci, vede (i) fenomenologii jako filosofickou disciplínu; (ii) samotnou theologii? Z této perspektivy bych rád na následujících řádcích předložil několik úvah.

\section{Vzájemná transformace fenomenologie a theologie}

Původně ironické označení „,theologický obrat" vzbudilo možná až příliš pozornosti a vyvolalo poněkud formální debatu o tom, zda theologický obrat nastal, či nenastal, zda nastat měl, či neměl, co nastalo a proč vlastně. Janicaud tak poněkud mimochodem uvedl na scénu normativní pojem pro domnělé přeznačení fenomenologie na theologii a úprk $\mathrm{z}$ hájemství lidské zkušenosti k autoritě (transcendentního) zjevení.

Obhajoba relevance autorů, proti kterým Janicaud zaměřil svoji kritiku, tak sleduje vždy stejné schéma: 1 . souhlas s Janicaudovým požadavkem na striktní rozlišení fenomenologie a theologie (font deux); 2. stanovisko, že k theologickému obratu $\mathrm{v}$ janicaudovském smyslu nedošlo. Někteří autoři tak zavedli pojem nová francouzská fenomenologie, aby se následně pokusili o její (pozitivní) zhodnocení a klasifikaci.

Pojem nová fenomenologie použili např. Gondek a Tengelyi ve svém úvodu Neue Phänomenologie in Frankreich. ${ }^{16} \mathrm{~J}$. Aaron Simmons použil týž termín jako alternativu a obranu proti „theologickému obratu“ již ve svém textu God in Recent French Phenomenology z roku $2008^{17}$ a spolu s Brucem E. Bensonem vydal první anglofonní úvod do problematiky pod týmž názvem: The New Phenomenology. A Philosophical Introduction. ${ }^{18}$ Simmons a Benson jsou filosofové náboženství, a dokládají tak, že především v této oblasti myšlenky Levinase, Mariona, Henryho, Chrétiena atd. silně rezonují. Benson dokonce vyslovuje názor, že v celé debatě nejde o theologii, ale o samotnou podstatu fenomenolo-

16 H. D. Gondek - L. Tengelyi, Neue Phänomenologie in Frankreich, Berlin 2011.

17 J. A. Simmons, God in Recent French Phenomenology, in: Philosophy Compass, 3, 2008, str. 910-932.

18 J. A. Simmons - B. E. Benson, The New Phenomenology. A Philosophical Introduction, London 2013. 
gie. ${ }^{19} \mathrm{Z}$ určitého pohledu tak post-janicaudovské vymezení proti theologii dává smysl. Poté co výše zmínění fenomenologové znovuobnovili těsný vztah mezi filosofií a náboženskými fenomény, jako např. zjevení, konverze, obět' a vůbec znovu uvážili otázku Boha a její možnosti ve filosofické reflexi, bylo třeba obhájit, že relevance zmíněných autorů nekončí za hranicí diskursu sympatizujícího s katolictvím, respektive monotheismem.

Simmons se otázce relevance theologického obratu, který žádným theologickým obratem nebyl, věnuje obšírně. Jak vyplývá již z názvu jeho knihy God and the Other. Ethics and Politics after the Theological Turn, ${ }^{20}$ theologie je heuristický nástroj a theologické inspirace francouzských fenomenologů musí být čteny jako možnosti rozšîrení pole myšlení a fenomenality, přičemž jejich aktualita $\mathrm{v}$ žádném př́ípadě není potvrzena ani není argumentováno v její prospěch. Neslavný theologický obrat tak paradoxně vyřazuje apologetický a konfesionální rozměr a fenomenologie zůstává iluminací zkušenosti, a nikoli prostředkem posvátné iluminace myšlení. Podobně návrat otázky Boha či apel Jiného je třeba číst filosoficky, tedy jako kritiku moderního - kartesiánského - pojetí subjektu a jako důsledné překonání subjektivismu ve fenomenologii poukazem na a-subjektivní možnosti fenomenologické analýzy. Francouzská fenomenologie tak nabízí alternativní ontologii vůči moderní metafyzice.

Zde naznačená linie je pokračováním v argumentaci, kterou přednesl Hent de Vries ve svém komprehensivním díle Philosophy and the Turn to Religion. ${ }^{21}$ Nikoli theologický obrat, ale filosofický návrat k tematice náboženství. Theologie je užitečný a účelný archiv. Vzít jej v potaz znamená znovu promyslet genealogii především eticky a politicky relevantních pojmů. A jak pokračuje Peter Jonkers, theologie jako jakási kritická teorie uschopňuje filosofii, respektive jí poskytuje výbavu $\mathrm{k}$ tomu, překročit $\mathrm{v}$ myšlení hranici metafyziky a otevř́ít nové pole fenomenality. ${ }^{22}$ Něco podobného nakonec vyjadřuje i Prášek, když o theologické aproximaci fenomenologie hovoří jako o „sekularizaci

19 B. E. Benson, Introduction, in: B. E. Benson - N. Wirzba (vyd.), Words of Life. New Theological Turns in French Phenomenology, New York 2010, str. 1-12.

20 J. A. Simmons, God and the Other. Ethics and Politics after the Theological Turn, Bloomington 2011.

21 H. de Vries, Philosophy and the Turn to Religion, Baltimore 1999.

22 P. Jonkers, God in France. Heidegger's Legacy, in: P. Jonkers - R. Welten (vyd.), God in France. Eight Contemporary French Thinkers on God, Leuven 2005, str. $1-42$. 
některých dříve theologických témat". Strategie contra et cum (tj. nová francouzská fenomenologie není theologie a theologická agenda nemá ve fenomenologii co pohledávat) nás tak dovedla k obrácení autora Theologického obratu naruby. Nikoli podřazení fenomenologie theologickému imperialismu, ale vysvobození z metafyzických spárů konceptuální idolatrie, která je problémem náboženských i sekulárních ideologií. Nikoli theologický obrat, ale filosofická rekuperace theologických témat ve prospěch filosofického myšlení, a tedy filosofický obrat či návrat (re-turn) k náboženství.

Společným jmenovatelem post-heideggerovské francouzské fenomenologie tedy není theologická konverze, ale exces, hyperbolická možnost nemožného, rehabilitace druhého jakožto skutečně jiného; to vše myšleno $\mathrm{v}$ jakémsi apofatickém momentu a vyjádřené v kenotickém tónu.

Simmons a další převážně anglosaští autoři, stojící v tradici kontinentální filosofie náboženství, nalezli ve francouzské fenomenologii alternativní diskurs k převažující analytické filosofické theologii. Oproti konfesionalismu filosofie „plantingovského“ typu nepředřazují fenomenologové své epistemic allegiances vlastnímu filosofickému myšlení (jak neúnavně zdůrazňoval Levinas a nepřestává zdůrazňovat Marion). Zatímco analytická filosofie náboženství se hrdě proměňuje v theologii (filosof se stává theologem, a korunuje tak své snažení), kontinentální tradice mluvení o Bohu nabízí kritiku a inspiraci pro zkoumání obecné lidské zkušenosti. ${ }^{23}$

Jestliže Prášek ve svém textu chápe fenomenologii inspirovanou dříve theologickými tématy jako rozšîrení pole fenomenality a vnímá ji jako prohloubení fenomenologického myšlení, filosofie náboženství zdůrazňuje rehabilitaci náboženské zkušenosti jako platného fenoménu. Z důvodu ztráty jednotného interpretačního rámce světa, který dříve náboženství poskytovalo, tak dnes fenomenologie ve svém zaměření na obecné struktury lidské zkušenosti slouží jako adekvátní modus pro uchopení právě otázky Boha a koherentní zkoumání limitní zkušenosti, včetně té náboženské, tedy jako jistá nekonfesionální postmoderní apologetika. ${ }^{24}$

Tento kursorický pohled na pokusy obhájit relevanci theologického obratu, které na jedné straně odmítají Janicaudovu diagnózu, na straně

23 J. A. Simmons, Living in the Existential Margins. Reflection on the Relationship between Philosophy and Theology, in: Open Theology, 1, 2019, str. 83-96.

24 C. Gschwandtner, Postmodern Apologetics? Arguments for God in Contemporary Philosophy, New York 2013. 
druhé však pevně drží požadavek radikálního rozdělení disciplín, ovšem budí otázku: není př́edstava theologie jako „archivu“ či „dříve theologických témat" přece jen poněkud reduktivní? Je theologie skutečně pouhý heuristický nástroj bez dalšího významu? Jde pouze o hyperbolický jazyk náboženského diskursu, citlivost k hraniční zkušenosti, kritickou výbavu apod., které filosofii umožňují tematizovat netematizovatelné? Ambici stát se novými filosofy (nikoli theology), kteří připravují theologii cestu, nelze některým současným francouzským fenomenologům upřít. Nebylo by žádoucí opustit debatu o legitimitě, resp. oprávněnosti a neoprávněnosti vzájemné výměny inspirací mezi fenomenologií a theologií, když se s těmito transformacemi a přecházením z disciplíny do disciplíny setkáváme u samotných inkriminovaných autorů? Pomáhá nekončící debata o theologickém obratu jako normativní kategorii čemukoli? Ve fenomenologii spíše brání vidět relevanci theologické inspirace jako zdroje pro ukazování nových fenoménů. Filosofie náboženství ve sveřepém ujišt'ování všech o naprosté de-theologizaci své agendy dovedla sebe samu na pokraj krize vlastní identity. ${ }^{25}$

Theologický obrat ve smyslu, jaký mu přisuzuje Janicaud, tj. theologizace fenomenologie, neproběhl. Nemá však pravdu Jean Greisch, že směr, kterým Janicaud uvažuje, je v zásadě správný, ačkoli apokalyptické závěry o narušení fenomenologické orthodoxie, byla-li kdy nějaká, se se skutečností míjejí ? ${ }^{26}$ Vzájemné působení a výměna mezi theologií a fenomenologií se ukazují jako reálný stav věcí. Ustanovit pojem theologického obratu jako deskriptivní kategorii pro jistý směr současné fenomenologie tak může být nejen přehledné, ale i užitečné. Pojem vykazuje potenciál otevírat nové otázky a horizonty. V tomto deskriptivním smyslu jsme použili termín theologický obrat v naší knize Transforming the Theological Turn. ${ }^{27}$ Theologický obrat tak nemusí nutně znamenat preskripci fenomenologické metody. Jedná se spíše o výzvu pohybovat se v prostoru mezi fenomenologií a theologií a odvážit se, řečeno spolu s Emmanuelem Falquem, překročit Rubikon.

25 Palgrave Communications (2018-2019) zveřejnily na téma krize identity filosofie náboženství řadu textů v open-access režimu: https://www.nature.com /collections/xzdznbgdwg\#phil-of-religion, navštíveno 4. 6. 2020.

26 J. Greisch, The Same and the Other, str. 69.

27 M. Koci- J. Alvis (vyd.), Transforming the Theological Turn. Posun významu je patrný také u S. DeLay, Phenomenology in France. Philosophical and Theological Introduction, London 2018. Theologie a filosofie se setkávají. 


\section{Kdo se bojí theologie?}

Petr Prášek vyjadřuje názor, že Janicaud předkládá až př́liš jasné stanovisko o tom, co je to fenomenologie. Dovolil bych si zde doplnit, že totéž lze u zmíněného autora říct také o statusu theologie. Janicaud má problém nejen s theologií, s theologickou inspirací fenomenologie, ale i s tím, že by fenomenologie snad mohla čímsi přispět theologii, nebot' jeho definice theologie je reduktivní. Nejedná se samozřejmě o problém, který by byl spjat výlučně s Janicaudem. Úzká až úzkoprsá představa theologie se objevuje u celé řady autorů, především filosofů náboženství, kteří s autory theologického obratu pracují, avšak nikdy nezapomenou zdůraznit, že jejich zájem je přísně de-theologizovaný. Výzva Emmanuela Falquea, že „více theologizovat znamená lépe filosofovat“, ${ }^{28}$ tak logicky působí jako rudý hadr na rozdrážděného býka. Raný Patočka by se nerozpakoval označit podobné výzvy za theologický imperialismus a Janicaud, snad jako by tušil, že podobná slova jednou zazní, se nerozpakuje vyřknout: „Kostky jsou vrženy, o všem podstatném je rozhodnuto a víra se majestátně tyčí v pozadí. Čtenář bryskně konfrontovaný s absolutnem se ocitá v pozici katechumena, jenž má jedinou možnost, totiž vnikat do svatých slov a majestátních dogmat.“29

Ano, zde se ukazuje jádro problému: theologie vrhá filosofa do pozice učedníka, který musí být zasvěcen do tajemství a neměnných dogmat, o nichž pojednává a jejichž vysvětlení podává věda o víre. Zatímco filosofie je privilegovaný diskurs otevřené dějinné debaty a nepředpojaté neutrality, theologie je singulární, vertikální diskurs poslušný předem rozhodnutým ahistorickým, zjeveným pravdám, tj. daným jednou provždy. Bezpochyby slyšíme echo Heideggerovy kritiky theologie jako pozitivní - ontické - vědy.

Ve slavné eseji Fenomenologie a theologie ${ }^{30}$ z pozdních dvacátých let minulého století Heidegger označuje theologii jako pozitivní, protože má své, již dané positum. Filosofie - jako ontologická disciplína - je naproti tomu otevřena každé otázce. Tato Heideggerova klasifikace a rozlišení disciplín mnohým stačí k tomu, aby positum theologie ztotožnili s pozitivním, již daným obsahem. Na tomto základě pak postulují jakýsi autoritativní seznam propozic zjevených Bohem a prijatých vírou. Theo-

28 E. Falque, Crossing the Rubicon. The Borderlands of Philosophy and Theology, přel. R. Shank, New York 2016, str. 25 a také 151-152.

29 D. Janicaud, Na rozhraních fenomenologie, str. 19.

30 M. Heidegger, Phänomenologie und Theologie, Frankfurt a. M. 1970. 
logie tedy neobjevuje to, co se ukazuje - jeví. Theologie jako věda víry interpretuje to, co se již ukázalo - zjevilo.

Je třeba uznat, že někteří theologové se ochotně chápou Heideggerovy kritiky a vítězoslavně volají: Vidíte, sám Heidegger uznává, že theologie je objektivní věda, která má právo zasednout s ostatními vědami u jednoho stolu (a ukrojit si tak svůj díl z rozpočtu na financování vědy). ${ }^{31}$ Theologové tak paradoxně hrají roli užitečných idiotů, když asistují při udržování obecného přesvědčení, že v jejich prrípadě běží o pozitivní, objektivní a přísnou vědu operující s logickými axiómy zahalenými do sebe-referenčního pojmového aparátu, který vede nakonec pouze k tomu, jak se jednou vyjádřil John D. Caputo, že „,theologii dnes již nikdo nevěří, a to $\mathrm{z}$ dobrého důvodu“.32

Je ovšem Heidegger ve svém kritickém pohledu skutečně takto schematický? Text německého filosofa by si jistě zasloužil hlubší analýzu. ${ }^{33}$ Zde si dovolím pouze několik upřesnění. Přestože Heidegger nepochybuje, že theologie náleží mezi ontické vědy, podtrhuje, že rozhodně není srovnatelná např. s fyzikou či biologií. Theologie jako věda víry není založena na objektivním pozorování a experimentálním ověřování nějakého předem daného seznamu propozic či hypotéz. Theologie je konceptuální reflexe křest'anské existence. Ono positum theologie je tedy na prvním místě žitá zkušenost a cílem theologie je kultivace této zkušenosti. Jinými slovy, ontické se nachází v těsné blízkosti ontologického. Proto Heidegger neváhá, navzdory jasnému rozlišení disciplín, potvrdit, že věda víry potřebuje filosofii jako svůj ontologický korektiv. Tak jako zkušenost s bytím-ve-světě předchází rozhodnutí reflektovat tuto zkušenost z perspektivy theologické, tak samotná theologie nemůže přeskočit pole zkušenosti k nějaké samo dané logice „Boží perspektivy“.

Theologie nemůže než učinit pozici víry problematičtější. Pozice katechumena, abychom parafrázovali Janicauda, se tak ukazuje jako poněkud prekérní. Fenomenologie, která se otevírá theologii, v žádném případě od druhé jmenované nedostává žádné hotové obsahy myšlení. Fenomenologii jako fundamentální reflexi struktur lidské zkušenosti

31 Takto se Heideggera poněkud mylně dovolává např. T. F. Torrance, Theological Science, London 1969.

32 J. D. Caputo, The Sense of God. A Theology of the Event with Special Reference to Christianity, in: L. Boeve - Ch. Brabant (vyd.), Between Philosophy and Theology, Farnham 2010.

33 Pokusil jsem se o takové čtení in: M. Koci, Thinking Faith after Christianity. A Theological Reading of Jan Patočka's Phenomenological Philosophy, Albany 2020, str. 23-27. 
a jejího myšlení se zde naopak otevírají možnosti nové. Kdo se bojí konfrontace s theologií? A proč?

Výše zmíněná výzva, kterou provokativně vyslovil Emmanuel Falque, tak neodkazuje k rekonstituci filosofické práce na základě theologického zdroje. Meritem věci je ukázat, že tak jako theolog a filosof mohou směle sdílet ke svému bádání jednu knihovnu, přičemž tentýž fond jim bude navzdory rozdílným důrazům k užitku, stejně tak se filosofie, a zvlášt' fenomenologie $\mathrm{s}$ theologií, mohou setkat na poli zájmu o lidskou zkušenost.

V mezinárodní diskusi se hrany již obrušují. Joseph Rivera v nedávno zveřejněném textu o theologickém obratu odhaluje mýtus theologie jako bezprostřední danosti, a tím zve filosofii (znovu) spatřit plodnost myšlení, které se v napětí mezi theologickou a fenomenologickou perspektivou může ukázat a být ku vzájemnému prospěchu. ${ }^{34}$ Řečeno jinak, theologické fenomény nepřestávají být fenomény. A tak když je např́íklad Marionova fenomenologie daru či danosti inspirována určitými theologickými myšlenkami (a dost možná vede svého autora k jistým theologickým cílům, jak si správně všímá Prášek), nejedná se o vpád nějakých absolutních, čistých a bezprostředních motivů, které by jakkoli chtěly obejít imanenci lidské zkušenosti, a snad dokonce vrhaly subjekt do bezvýchodné pasivity, v núž jako jediná možnost zůstává přijmout neměnná dogmata. ${ }^{35}$ Marion (stejně jako další reprezentanti theologického obratu) zůstává fenomenologem, který je otevřen theologii, nebot' ta mu pomáhá vidět. A jakým způsobem se francouzští fenomenologové na základě theologických inspirací dívají na svět, přehledně popsal Prášek ve svém textu. Je opravdu nutné ostentativně označovat tuto cestu fenomenologie př́domkem bez theologie? Nepoukazuje celá debata o obratu naopak k prrirozené inklinaci fenomenologie $\mathrm{k}$ theologii, resp. jisté theologické otevřenosti fenomenologie?

Na otázku, zda ve francouzské fenomenologii došlo k theologickému obratu, bychom tak mohli odpovědět, a tím vyřadit pejorativní nádech celé debaty, že fenomenologie vždy vykazovala jistou aproximaci

34 „Bezprostřední danost je mýtus. ... Boží zjevení jako specifická forma danosti odkazuje k mediaci tajemství Boha v rámci komunity interpretace. Názor, že se v prŕípadě Zjevení jedná o okamžitě bezprostřední impresum ze strany Boha, je třeba vyřadit." J. Rivera, The Myth of the Given? The Future of Phenomenology's Theological Turn, in: Philosophy Today, 62, 2018, str. 182-183.

35 B. Klun, Transcendence and Acknowledgement. Questioning Marion's Reversal in Phenomenology, in: Bogoslovni Vestnik/Theological Quarterly, 2, 2019, str. 367-379. 
směrem k theologii: „Fenomenologie nikdy nebyla tak neutrální, jak ji představuje Janicaud. Žádný theologický obrat ve skutečnosti neproběhl. Theologie ovšem byla vždy skrytou pravdou a živoucím středem fenomenologie.“36 Že se nejedná o př́liš radikální výrok, ukazují některé nedávné historické studie. Mám na mysli především Converts to the Real od E. Baringa ${ }^{37}$ a již dřívější text The „German Fathers “ of the Theological Turn in Phenomenology od S. Camilleri. ${ }^{38}$ Jádro problému ožrejmuje sám Marion, který v publikované konverzaci s Danem Arbibem na jedné straně podtrhává, že k žádnému theologickému obratu nedošlo, avšak doplňuje vysvětlení, že fenomenologii pojí s theologií jistá přirozená tendence. ${ }^{39}$

Na problém se tak lze dívat dvěma způsoby. Zastánci fenomenologie bez theologie odmítají Janicaudův soud, nebot' při pohledu do theologického archivu vnímají pouze jednosměrnou inspiraci fenomenologie. $\mathrm{Na}$ druhé straně stojí ti, pro které theologie není historický relikt ani pouhý archiv a anamnéza současných etických, politických a antropologických pojmů. Theologie je živoucí diskurs, který odkazuje k poli jevení ve světě, tj. k poli, které by nemělo zůstat stranou pozornosti fenomenologie, nebot' se bytostně týká lidské zkušenosti, bytí a existence. Jednosměrné pojetí je nahrazeno obousměrnou výměnou, a dokonce vzájemnou transformací disciplín při jejich setkání. K theologickému obratu v janicaudovském smyslu nedošlo, nebot' fenomenologie vždy vykazovala citlivost k theologii, která ji doprovázela.

Když se Heidegger vyslovil o theologickém původu, který jej nasměroval na cestu myšlení, ${ }^{40}$ možná tím nechtěl naznačit nic jiného, než že rozlišení disciplín fenomenologie a theologie nemusí nutně vést $\mathrm{k}$ jejich vzájemné exkluzi. Fenomenologie a theologie jsou v napětí, nebot' obě jsou, abychom parafrázovali Jean-Yves Lacosta, pravé dcery dějin. ${ }^{41}$

36 I. Leask, Was There a Theological Turn in Phenomenology?, in: Philosophy Today, 62, 2018, str. 150.

37 E. Baring, Converts to the Real. Catholicism and the Making of Continental Philosophy, Cambridge (Mass.) 2019.

38 S. Camilleri, The „German Fathers “ of the Theological Turn in Phenomenology. Scheler, Reinach, Heidegger, in: The Heythrop Journal, 4, 2014, str. 545-552.

39 J.-L. Marion, The Rigor of Things. Conversations with Dan Arbib, přel. Ch. M. Gschwandtner, New York 2017, str. 126.

40 M. Heidegger, Unterwegs zur Sprache, Pfüllingen 1959, str. 96.

41 J.-Y. Lacoste, More Haste, Less Speed in Theology, přel. O. O'Donovan, in: International Journal of Systematic Theology, 9, 2007, str. 263-282, zde str. 282. 


\section{Poznámka k úkolu theologie}

Zápas o theologický obrat tak není jen debatou o podstatě fenomenologie, ale jde také o vyjasňování definice theologie. László Tengelyi neváhá označit novou francouzskou fenomenologii za zdroj radikálně proměněného smyslu theologie. Smyslu, který dokáže odkrýt právě fenomenologie. ${ }^{42}$ Abychom otočili Janicaudovu metaforu, v jistém smyslu lze jistě mluvit o nových filosofech theologie. Marionovy snahy o fenomenologii jako první filosofii, Henryho fenomenologie křest'anství, Lacosteho analýzy liturgické existence, Chrétienova fenomenologie modlitby, Falqueovo osvobození theologie skrze filosofii, to vše jsou hozené rukavice, které čekají na zdvihnutí ze strany theologů. Theologický obrat začíná u theologických inspirací, které radikálně reinterpretuje skrze fenomenologickou perspektivu, avšak tyto myšlenky se vrací zpět v podobě, která má pro theologii bezpochyby zásadní relevanci. Theologický obrat nejen rozšiřuje pole fenomenologického zkoumání, ale má také ambici vybavit theologii konceptuálním aparátem, který její mnohdy strnulou podobu chce transformovat v rigorózní výkon myšlení.

Provokativní, opovážlivé, skandální, bude se ozývat z theologických kateder. „Filosof nebude pomáhat theologovi,“ ̌rekl by Patočka. ${ }^{43}$ A Janicaud, zdá se, nejen že chce zabránit theologizaci fenomenologie, ale nemá uznání ani pro možnost fenomenologické theologie. ${ }^{44}$ Jakoby mimochodem přichází Falque, theolog a fenomenolog v jedné osobě, s konstatováním, že nemáme jinou zkušenost Boha než lidskou zkušenost. ${ }^{45} \mathrm{Z}$ hlediska fenomenologie lze číst Falqueova slova jako vytyčení schůdné cesty pro filosofické promýšlení otázky Boha, která nemůže opustit sféru imanence. Nenechme se však mýlit. Falque právě zde překračuje Rubikon a konfrontuje theologa. Tak jako filosofie ve svých dějinách zapomíná na otázku bytí, tak theologie ztrácí povědomí o tom, že nemá jinou než lidskou - tělem a konečným bytím zprostředkovanou -

42 L. Tengelyi, On the Border of Phenomenology and Theology, in: J. Bornemark - H. Ruin (vyd.), Phenomenology and Religion. New Frontiers, Södertörn 2010, str. 21.

43 J. Patočka, Theologie a filosofie, str. 19.

44 D. Janicaud, Na rozhraních fenomenologie, str. 90-93 a 107-108.

45 Falque se v tomto smyslu vyjadřuje velmi často. První zmínku můžeme nalézt v jeho eseji Théologie et philosophie. Nouvelles frontières, in: Études, 2, 2005, str. 205. Dále pak myšlenku rozvíjí in: týž, The Metamorphosis of Finitude. An Essay on Birth and Resurrection, New York 2012, str. 6; rovněž in: týž, Crossing the Rubicon, kap. 5. 
zkušenost. Rozdíl oproti filosofii lze najít v tom, že theologie nezůstává u myšlení možnosti, ale připouští reálnou existenci transcendence. To ovšem nikterak nevyvrací nepřekročitelnou imanenci (impassable immanence), které se theolog může naučit od fenomenologa.

Fenomenologii otevřená theologie odmítá preemptivní pojetí nekonečnosti a osvobozuje se ze sebe-referenčního tautologického kruhu. Spolu s Falquem se odvažuji říct, že bytí a čas musí být první kapitolou každé theologie. Prvním slovem theologie, která je nejen racionální (Marion sleduje mnohdy právě tento theologický cíl), ale také kredibilní, je konečnost bytí ve světě. Nepředchází svět zjevení? Nedává se to, co theologie nazývá zjevení, ve světě? A není veškerý zájem o knihu zjevení ( $l i$ ber Scripturae) zaměřn k porozumění celku knihy světa (liber mundi)?

Je úkolem theologie podat správnou interpretaci zkušenosti excesivní danosti, anebo starost o lidské per se? Neměla by theologie, která chce být skutečně existenciálně relevantní, přijmout jistou intelektuální pokoru? Ta nemusí zahrnovat v kontextu theologického obratu tolik skloňovaný projekt překonání metafyziky ${ }^{46}$ ale uzávorkování preemptivní nekonečnosti jako zdroje poznání a epistemologické jistoty, která ční nad autenticky lidskou a všem společnou zkušeností konečnosti. Konečnost jako ontologická danost, nikoli jako pouhá privace, otevírá možnost nového pojetí theologie, které není proniknutím Boha $\mathrm{v}$ jeho esenci, ale spíše bonaventurovským vstupem Boha do mysli.

Při četbě autorů theologického obratu nedochází pouze k rozšíření pole theologie, ale především k transformaci theologické gramatiky. Fenomenologie chce porozumět světu jako celku. Theologie, která se odváží fenomenologii naslouchat, si rozumí jako zkoumání struktur lidského bytí ve světě coram et cum Deo.

Platí-li, že fenomenologie není tak úplně bez theologie, v opačném gardu se ukazuje, jak je důležité, aby theologie nebyla bezfenomenologie.

\section{Závěr}

Zdá se mi, že musíme rozlišit dvě otázky: (1) Kam mírí Janicaud svojí kritikou a co se z ní můžeme naučit? (2) Co přinesla následná diskuse

46 Relevanci metafyzického myšlení v dialogu s Patočkovou fenomenologickou filosofií jsem se pokusil ukázat v eseji Metaphysical Thinking after Metaphysics. A Theological Reading of Jan Patočka's Negative Platonism, in: International Journal of Philosophy and Theology, 1-2, 2018, str. 18-35. 
o theologickém obratu? K první otázce lze říct, že fenomenologie se musí jistě bránit theologickému založení svého myšlení, tj. odmítnout epistemologický fundacionalismus předem a bezprostředně daných dogmat. Řečeno jinak: Filosofovat ze zjevení je zapovězeno. Nejedná se ovšem o uměle vytvořený problém, který míjí to podstatné? Totiž aproximace a průduchy mezi fenomenologií a theologií, skrze které se obě disciplíny vzájemně ovlivňují. Inspirace ze sféry theologie, byt' se nejedná o konfesní atak na rigoróznost fenomenologie, bezpochyby filosofické zkoumání proměňuje. A tím se dostáváme k odpovědi na druhou otázku. Příliš mnoho pozornosti, kterou fenomenologie a filosofie náboženství věnovala formální otázce (ne)legitimity (ne)theologického obratu, nás svedlo na scestí. Namísto prohledávání nově otevřeného prostoru napětí došlo - proč to nepřiznat? - ke kolizi mezi theologickým a filosofickým myšlením a k prohloubení př́kopů. Rozdělující zdi byly posíleny a hraniční přechody na mnoha místech uzavřeny. Lacosteho pozvání k opatrnému, postupnému odstranění hranic mezi theologií a filosofií, Falqueova výzva překročit Rubikon byly oslyšeny. Marionova první filosofie, Henryho fenomenologie křest’anství ani Chrétienova theopoetika si až na ojedinělé výjimky cestu do theologie nenašly. Jakkoli zde narážíme na problematické a diskutabilní koncepty, odsunout je stranou ve jménu disciplinárního purismu, domnělé orthodoxie apod. znamená minout se s výzvou myslet.

Theologický obrat je vlastně dvojí výzva. Směrem k filosofii či fenomenologii bude stěžejní vystavit se myšlení autorů, kteří pod hlavičkou theologického obratu figurují, avšak jsou u nás jen málo reflektovaní. Neméně důležité ovšem bude nezabřednout ve formálních otázkách ani nezůstat $\mathrm{u}$ rozširreného pole fenomenality, které dřívější fenomenologie z různých důvodů nechávala stranou. Opravdovou výzvou je tematizovat choc en retour, který fenomenologie zakouší ve své otevřenosti theologii. Z mého pohledu ještě důležitější výzvou je ta směřující k theologii. Česká theologie, pokud něco takového vůbec existuje, doposud nevykazovala př́liš živý zájem o současnou filosofii, či snad dokonce fenomenologii. Ztracena v historizujícím pojetí vlastní disciplíny a překladové činnosti si inspiraci z aktuální mezinárodní debaty bere spíše nepřímo. Zprofanovaná v narativním přeznačení zkušenosti na všeobjímající spirituální př́iběh je bez relevance mimo konfesně vymezený rámec. ${ }^{47}$ Theo-

47 Tuto slepou uličku theologie jsem podrobil kritice v eseji Theologii myslet, nikoliv dělat. Několik kritických poznámek k otázce „,co je theologie?“, in: Studia Theologica, 22, 2, 2020. 
logii vystavené theologickému obratu krystalizuje pod rukama rigorózní metodologický aparát pro reflexi své pozice ve světě. K tomu všemu je třeba prripočítat, že výzva osvobodit theologii filosofií či theologii vybavit fenomenologickou první filosofií je formulována z pozice sympatizující s úkolem theologického myšlení, ba dokonce z vášně pro tento úkol.

Tento text bezpochyby otevřel více otázek, než poskytnul odpovědí. Autor je ovšem přesvědčen, že to jsou právě tyto a mnohé další otázky, které musíme vyslovit, abychom opustili své pohodlné př́bytky jasně vymezených hranic disciplín, kde je nám př́ijemně a pohodlně. Theologický obrat je výzva i provokace. Bude zajímavé sledovat, jak se této výzvy zhostí česká, případně československá filosofická a theologická obec.

Martin Kočí 